\title{
PROTECTING THE CHILD VICTIM IN SEXUAL OFFENCES: IS THERE A NEED FOR SEPARATE LEGAL REPRESENTATION?*
}

\author{
Desan lyer \\ BProc LLM LLD \\ Lecturer in the Department of Private Law \\ University of Zululand, KwaDlangezwa \\ Attorney of the High Court of South Africa \\ Lonias Ndlovu \\ Dip Ed LLB LLM LLD \\ Senior Lecturer in the Department of Private Law \\ University of Zululand, KwaDlangezwa
}

\section{SUMMARY}

The number of children being sexually violated on a daily basis continues to escalate against a backdrop of a dearth in the conviction rate of their attackers. This is notwithstanding global efforts being made to protect children from the harrowing experience of being sexually violated. Creative measures such as the introduction of innovative child legislation have been largely neutralized by the inability of the criminal justice system to complement the child's healing process. The gulf between policy and practice has given rise to a lack of protection in respect of the rights of children. In this paper, we seek to highlight the gaps in the South African criminal justice system when it comes to safeguarding the interests of the minor complainant during the criminal process. We analyse key legislative instruments which purport to protect the minor victim. The analysis is aimed at determining whether or not the specified key provisions are in conflict with the Constitution. The introduction of separate legal representatives for child complainants is evaluated as an option in improving the plight of young child victims. The paper then concludes on an optimistic note by boldly opining that in line with legal developments in other international jurisdictions, the South African criminal justice system can accommodate the legal novelty of introducing separate legal representation for child victims.

This is a revised version of a paper presented at the Annual Congress of the Society of Law Teachers of Southern Africa, held at the University of Stellenbosch, from 17-21 January 2011. 


\section{$1 \quad$ INTRODUCTION}

"The children of the world are innocent, vulnerable and dependent. They are also curious, active and full of hope. Their childhood should be one of joy and peace, of playing, learning and growing. Their future should be shaped in harmony and cooperation. Their lives should mature, as they broaden their perspective and gain new experiences"

With the above statement in mind, it is ironic that despite global efforts being made to realize such commitments, children continue to be abused and violated, often by those who ought to protect them. This is illustrated by increasing reports of sexual crimes on a daily basis in the media. The conviction rate for rape and sexual offences matters in South Africa, and in most countries around the world, has always been an area of concern. ${ }^{2}$ Even more glaring is the low conviction rate in rape matters involving child complainants. ${ }^{3}$ It seems unfathomable that in the present climate of legal awareness, the number of children being sexually violated on a daily basis continues to escalate against a backdrop of a dearth in the conviction rate of their attackers.

Despite numerous attempts being made to protect the rape victim from what is often described as a painful and difficult courtroom experience, ${ }^{4}$ the psychological and emotional scarring that accompanies such an experience will in all likelihood haunt the child victim well into adulthood. It is extremely difficult for a child to recover from a process that destroys whatever dignity, innocence and self-belief that may have still been left after an incident of rape. Child innocence and naivety are supposedly meant to be a shield against the harshness and brutality of the outside world, but unfortunately the criminal justice system is not designed to provide the desired protection that is required after the ordeal. It is a notable cause for concern when the judiciary utters words such as, "there is much that is left to be desired in the present state of our criminal justice system and that, in many instances,

1 World Declaration on the Survival, Protection and Development of Children: World Summit for Children: World Summit for Children 30 September 2001 published in the Report on Sexual Offences against Children by the South African Human Rights Commission April 2002.

2 See generally United Nations Office on Drugs and Crime, Handbook for Professionals and Policymakers on Justice Matters Involving Child Victims and Witnesses of Crime (2009) 6583 (hereinafter "UNODC 1"). On a related note, in a study conducted by the Human Sciences Research Council (HSRC) from 1993 to 1995, it was found that crimes against children were increasing by an average of $28 \%$ per year and children were most likely to be the victims of sexual offences. According to a study by the United Nations Office on Drugs and Crime (hereafter UNODC 2) entitled "Rape Statistics - South Africa and Worldwide 2011" http://www.rape.co.za/index.php?option=com_content\&task=view\&id=875 (accessed 2012-02-29), in 2010, nearly half of all sexual crimes reported were committed against children. This suggests that whatever has been done thus far is not enough.

3 Martin "Child Sexual Abuse: Preventing Continued Victimisation by the Criminal Justice System and Associated Agencies" 1992 Family Relations 41 330-333.

4 Conradie and Tanfa "Adjudication of Child Victims of Rape and Indecent Assault in Gauteng" 20056 Child Abuse Research in South Africa 15; and Lipovsky, Tidwell, Crisp, Kilpatrick, Saunders and Dawson "Child Witnesses in Criminal Court: Descriptive Information from Three Southern States" 1992 Law and Human Behaviour 635-650. 
neither the courts nor their supporting institutions succeed in giving due recognition to the paramountcy of children's interests."

Even though strides have been made in introducing innovative child legislation in recent times, it is unfortunate that these creative measures have largely been neutralized by the inability of the criminal justice system to effectively assist in the child's healing process. ${ }^{6}$ It is unfortunate that the gulf between policy and practice has given rise to a lack of protection in respect of the rights of children. ${ }^{7}$ The devastating and profound effects of sexual abuse on children are exacerbated by the abuse experienced by the children during the criminal justice process which fails to take into account their cognitive development. $^{8}$

This article seeks to highlight the existing and perceived gaps in the South African criminal justice system vis-à-vis safeguarding the interests of the minor complainant during the criminal justice process. Key legislative instruments which purport to protect the minor victim are analysed in order to determine whether or not they are in conflict with the Constitution. The introduction of separate legal representatives for child complainants is also explored as a possible option for improving the plight of these young victims. Finally, through a brief comparative narrative with other countries, the paper recommends that the South African criminal justice system should seriously consider taking deliberate steps of allowing legal representation for child victims.

\section{THE SOUTH AFRICAN LEGAL AND POLICY FRAMEWORK}

The successful prosecution of sexual offences against children lags behind societal expectations across most countries in the world. ${ }^{9}$ Unfortunately, South Africa has the stigma of having one of the highest incidences of rape in the world. ${ }^{10}$ According to statistics released by South African Police Service in 2010, the official figure for sexual crimes in 2003 was 66079 and this figure had risen nearly a decade later to 68332 in $2010 .{ }^{11}$ A significant percentage of the 2010 figure, namely 27 417, included sexual crimes against children and sixty percent of the crimes were committed against children below the age of 15 years. Even more revealing is the fact that

\footnotetext{
S v Mokoena; S v Phaswane 2008 (2) SACR 216 (T) 231.

Waterhouse "The Impact of Changing Criminal Justice Responses to Child Victims of Sexual Abuse" 20084 Criminal Justice Initiative Occasional Paper 2.

Ibid.

8 Potgieter "The Internal Trauma of the Sexually abused Child" 20001 Child Abuse Research in South Africa 58.

9 See Bottoms, Najdowski and Goodman Child Victims, Child Offenders: Psychology and the Law (2009) 2.

10 According to UNODC 2 1, it is estimated that a woman born in South Africa has a better chance of being raped than learning how to read.

11 Crime Information Management Sheet released by the SAPS titled, "Crime in RSA National Total for April 2003/2004 to 2009/2010" www.saps.gov.za/statistics/reports/ crimestats/2010/totals.pdf (accessed 2011-04-20).
} 
twenty-nine per cent of these sexual offences involved children below 10 years.

It is important to bear in mind that most sexual offences go unreported so the figures released by the South African Police Services reflect only those matters that were reported to the police. The actual number of incidents of rape in 2010 could be closer to 1 million. ${ }^{12}$

The actual reality is that rape statistics in South Africa have increased during the past decade despite statutory reforms being introduced to address the crisis. South Africa does have a comprehensive statutory framework which seeks to protect children. International legal instruments and domestic legislation also guide the protection of children's rights in South Africa. With specific reference to the international framework, South Africa ratified the United Nations Convention on the Rights of the Child in 1995. ${ }^{13}$ Through this ratification, South Africa undertook to domesticate the provisions of the Convention by inter alia, adopting legislative, administrative, social and educational measures to protect the child from all forms of physical or mental violence, injury or abuse including sexual abuse, neglect and negligent treatment. ${ }^{14}$

The obligation is wide in ambit and extends to the taking of appropriate measures to promote the physical and psychological recovery of the child victim in an environment that fosters the health, self-respect and dignity of the child. ${ }^{15}$ Likewise, by acceding to the African Charter on the Rights and Welfare of the Child, ${ }^{16}$ South Africa undertook to protect children from all forms of exploitation and sexual abuse by taking specific measures to prevent such abuse. South Africa is one of the 168 states worldwide that has ratified the United Nations Convention on the Elimination of all forms of Discrimination against Women, ${ }^{17}$ which aims to protect and promote women's rights.

In terms of the Constitution of the Republic of South Africa, ${ }^{18}$ the provisions contained in the Bill of Rights ensure the protection, promotion and respect of the rights of all South African citizens, including children. ${ }^{19}$

12 According to studies done by the National Institute of Crime Rehabilitation, only one in twenty rapes are reported. The full report is available at www.southafricaproject.org/goalsrape-prevention.php (accessed 2011-04-20).

13 Waterhouse "The Impact of Changing Criminal Justice Responses to Child Victims of Sexual Abuse - Good Intentions, Questionable Outcomes" 2008 Open Society Foundation 6.

14 Ibid.

15 Ibid.

16 OAU Doc. CAB/LEG/24.9/49 (1990), entered into force Nov. 29, 1999 South Africa acceded to the Charter on 7 January 2000. For a full text of the Charter, see Heyns and Killander Compedium of Key Human Rights Documents of the African Union (2007) 62-75.

17 Commonly known as CEDAW, with the full text published by the United Nations, Treaty Series vol 1249 13, came into force on 3 September 1981. South Africa ratified the Convention on the 15 December 1995.

18 Constitution of the Republic of South Africa 1996 (hereinafter "the Constitution").

19 From a purposive reading of $\mathrm{s} 8$ of the Constitution, it would seem the above submission does have a textual basis. 
The Constitution also gives prominence to the child's best interests in every matter concerning the child. ${ }^{20}$ The protection of every child from maltreatment, neglect, abuse or degradation is also guaranteed. ${ }^{21}$ South African courts have an obligation to protect children because of their vulnerability and uniqueness and this protection can be achieved by enforcing their rights.

A number of key legislative instruments such as the Children's Act, ${ }^{23}$ and the Criminal Law (Sexual Offences and Related Matters) Amendment $\mathrm{Act}^{24}$ was enacted to give effect to selected provisions of the Constitution and international instruments. Other statutory instruments such as the Child Care Act ${ }^{25}$ the Criminal Procedure $\mathrm{Act}^{26}$ and the Domestic Violence $\mathrm{Act}^{27}$ have been in force for a number of years with the common purpose of serving to protect the interests and well-being of the child at all material times.

With National Policy Guidelines for Sexual Offences being introduced into the system some time ago, ${ }^{28}$ commissions being set up to address the plight of these young victims, ${ }^{29}$ and a vast array of detailed municipal and international instruments being available, it is ironic that sexual offences against minors continue to spiral out of control.

\section{CURRENT PERCEIVED SHORTCOMINGS IN THE SOUTH AFRICAN LEGAL REGIME}

There have been many innovative models of service delivery being implemented in recent times but the performance of the criminal justice

$S$ 28(2) of the Constitution.

Per s 28(1)(d) of the Constitution.

22 Sachs J, delivering the majority judgment in $S$ v M (Centre for Child Law as Amicus Curiae) 2008 (3) SA 232 (CC) 244, held that courts are obliged to enforce children's rights rather than treat them as guidelines. See also $s$ 28(2) read together with $s$ 28(1) of the Constitution.

2338 of 2005.

$24 \quad 32$ of 2007.

74 of 1983.

2651 of 1977.

116 of 1998.

28 Namely the Victim Empowerment Policy, developed out of the 1996 National Crime Prevention Strategy; the Service Charter for Victims of Crime in South Africa (2004), designed by the Department of Justice and Constitutional Development and the Uniform Protocol for the Management of Victims, Survivors and Witnesses of Domestic Violence and Sexual Offences (2005), developed by the National Prosecuting Authority of South Africa.

29 See the South African Human Rights Commission Report entitled "Sexual Offences Against Children: Does the Criminal Justice System Protect Children?" 2002 http://www.sahrc.org.za/home/21/files/Reports/child_sexual_offences_report_april_2002.pdf (accessed 2012-02-02) In the report, the Human Rights Commission confirmed holding public hearings into sexual offences against children in order to determine the efficacy of mechanisms that were in place to protect children. Its findings were that the mechanisms in place fell short of the desired effect of protecting the interests and rights of the children. Recommendations were made calling upon all the role-players to make a special effort in improving the system, yet nearly a decade later, these very same problems continue to clog a system that has gone backwards in its effort to safe-guard the interests of the young victims. 
system in relation to child victims remains generally derisory. ${ }^{30}$ The lack of funding for organizations which provide victim support in the criminal justice system continues to be an area of concern. ${ }^{31}$ Many of these organizations are excluded from policy development. A policy ${ }^{32}$ providing for counselling support to child victims is inadequate and contentious. ${ }^{33}$ On this specific issue, Frank ${ }^{34}$ points out very succinctly that the Victims Charter, which also provides for counselling services for child victims, is limited in that it applies only to those victims who report the crime to the criminal justice system. ${ }^{35}$ We concur with this observation and further note that there are a number of other victims who may access services from the health and welfare systems or civil society but will not be afforded the same rights to access quality services. This observation hinges on the fact that the Charter does not contemplate reporting to health, civil society and welfare systems as equivalent to reporting through the criminal justice system.

The South African Human Rights Commission recommended developing a criminal justice system that is premised on the best interests of the child. ${ }^{36}$ In the report, the Commission found that police officers were generally not alert to the psychological state of children when dealing with sexually abused children. ${ }^{37}$ Further the report notes that very little feedback was given to the complainant and family concerning the progress of the investigation. ${ }^{38}$ On another level, it is noted with concern that the Department of Justice did not always monitor the compliance of National Policy Guidelines when dealing with child victims. ${ }^{39}$ Very glaringly, not all prosecutors were trained in handling sexual abuse cases and very few knew how to adopt a child-friendly approach. ${ }^{40}$

A genuine concern raised in the report was that not all proceedings were held in camera and separate waiting rooms were not always provided for victims and perpetrators. ${ }^{41}$ The undue delays in the handling of cases were a serious cause for concern as well. Magistrates at times lacked the training and skill to determine whether the child was competent to testify or not. ${ }^{42}$

\footnotetext{
Waterhouse 20084 Criminal Justice Initiative Occasional Paper 2.

Human Rights Commission 61 (see fn 11 above).

The Uniform Protocol for the Management of Victims, Survivors and Witnesses of Domestic Violence and Sexual offences (2005).

33 Ibid.

34 Frank "Quality Services Guaranteed? A Review of Victim Policy in South Africa" 2007 Institute for Security Studies 36.

Ibid.

6 Human Rights Commission 69-70 (see fn 29 above).

Human Rights Commission 61 (see fn 29 above).

Ibid.

Human Rights Commission 63 (see fn 29 above).

Human Rights Commission 64 (see fn 29 above).

Human Rights Commission 65 (see fn 29 above).

Human Rights Commission 71 (see fn 29 above).
} 
Intermediaries and social workers often failed to appear in court and at times the trial commenced without these support services being present. ${ }^{43}$

It was further reported that many attorneys failed to balance the interests of their client against the interest of the sexually abused child in a manner that reflected respect for section 28 of the Constitution. ${ }^{44}$ Despite recommendations being made nearly a decade ago to address these shortcomings in the South African criminal justice system, very little has been done to date as reflected by the crime statistics released in $2010 .{ }^{45}$ The accuracy of the crime statistics released by the South African Police Services remains a contentious issue because not all crimes are reported. ${ }^{46}$ According to the UNODC, with specific reference to the crime statistics from South Africa, welfare groups believe that the number of unreported incidents could be up to ten times that number. ${ }^{47}$ Under-reporting is a complex issue influenced by the psychological consequences of sexual assault such as denial, avoidance, subjective interpretation of the abuse and fear of the consequences of disclosing the abuse. ${ }^{48}$

The extent of under-reporting of sexual offences against children is unknown, but under-reporting is likely to be higher in cases involving children. ${ }^{49}$ This may be due to a host of factors such as the close nature of the relationship between the child and the perpetrator; the child being confused about, or feeling responsible for, the abuse; child's fear of reprisal by the perpetrator; child feeling protective of perpetrator or family members; social taboos relating to sex and sexual abuse, resulting in shame and embarrassment; engrained patriarchal norms which imply a child's dependence on close male family members which makes their exposure difficult; and complicity of family members in hiding the abuse..$^{50}$

The Constitution ${ }^{51}$ demands that a child witness who has been a victim of a sexual attack be protected against undue stress, and any form of emotional or psychological harm. ${ }^{52}$ Children are by their very nature vulnerable. A child is even more vulnerable when that child is the complainant in a criminal trial. Even before entering the criminal process,

43 Human Rights Commission 72 (see fn 29 above).

44 Ibid.

45 Crime statistics are available on the South African Police Service http://www.saps.gov.za/ statistics/reports/crimestats/2011/crime_stats.htm (accessed 2012-03-05).

46 UNODC 1. See also Waterhouse 20084 Criminal Justice Initiative Occasional Paper 2.

47 UNODC 1.

48 Battis Hypnotherapy and Childhood Sexual Abuse: The Experiences of Adult Survivors (Thesis D Litt et Phil (2005)) 21 www.etd.rau.ac.za/theses/available/etd-0911205-095638 (accessed 2012-02-05).

49 Waterhouse 20084 Criminal Justice Initiative Occasional Paper 2.

50 Waterhouse 20084 Criminal Justice Initiative Occasional Paper 2-3.

51 See $\mathbf{2} 28$ of the Constitution, which deals with the rights of children generally.

52 S 28(1)(d) provides that, "every child has the right to be protected from maltreatment, neglect, abuse or degradation". Even though the section does not specifically provide for protection against sexual abuse, " abuse" covers all forms. 
children who are victims of sexual abuse are scared, guilt-ridden and confused about the abuse. ${ }^{53}$

A major factor that impacts negatively on the experience of the child witness in court is a lack of understanding of what the court process entails. ${ }^{54}$ During the criminal process, the child is exposed to further trauma, possibly as severe as the trauma caused by the crime itself. ${ }^{55}$ This additional trauma stems from the child re-experiencing feelings of guilt, defencelessness, invasion and fear during the court process. ${ }^{56}$ Unfortunately, in a courtroom environment, there is a strong possibility that a child complainant may be subjected to stress and emotional scarring. It has also been observed that some adults also find it difficult to adjust to the cold, formalistic setting of a courtroom environment. If the courtroom environment rattles even adults, the effect is likely to be more disturbing and emotionally scarring for children.

A child complainant is not psychologically and emotionally mature enough to handle a criminal trial, and the South African criminal-justice system and its attendant processes fail to take into account the child's cognitive development. ${ }^{57}$ Children comprehend experiences and information differently to adults who are much more cognitively advanced. It is therefore imperative for people dealing with children in the criminal justice system to be skilled in effective communication in order to avoid uncertainty and misunderstanding that can arise during the communication process. ${ }^{58}$

The South African courts in recent times have expressed their concern over the inability of the South African criminal justice system to protect the young child complainant adequately. ${ }^{59}$

We submit that the largely adversarial system is in direct conflict with emotional needs of a child victim. ${ }^{60}$ Children are not mature enough to deal with the formalistic setting of a courtroom. Subjecting a child to foreign legal language and confrontational cross-examination without proper assistance cannot be in the best interests of the child. ${ }^{61}$ It is not easy for a child to

53 Summit "The Child Sexual Abuse Accommodation Syndrome" 19837 Child Abuse and Neglect 177.

54 Muller and Tait "Little Witnesses: A Suggestion for Improving the Lot of Children in Court" 19982 THRHR 241.

55 S v Stefaans 1999 (1) SACR 182 par 187F-G.

56 Conradie and Tanfa 20056 Child Abuse Research in South Africa 16.

57 Ibid.

58 Avery "The Child Abuse Witness: Potential for Secondary Victimisation" 19837 Criminal Justice Journal 47.

59 S v Mokoena; $S$ v Phaswane supra 231 (fn 5 above).

60 See Bala, Lindsay, and McNamara "Testimonial Aids for Children: The Canadian Experience with Closed Circuit Televisions, Screens and Videotapes" 200144 Criminal Law Quarterly Review 641-648.

61 S v Mokoena; S v Phaswane supra A55-B56 (fn 5 above). 
perform as a competent witness because emotions of fear, stress and anxiety impact on the quality of evidence provided by the child. ${ }^{62}$

According to Bertelsmann $\mathrm{J}$ in $S \vee$ Mokoena, ${ }^{63}$ children are ill-equipped to deal with a confrontational and adversarial setting in which adults dictate the subject matter. ${ }^{64}$ The learned judge went on to add that the child is an alien in the courtroom because our legal system was designed for adults. ${ }^{65}$ The colonial setting of a courtroom with its tradition of extraordinary dress, formalistic language and ritual procedure adds to the alienation that children experience in these unusual settings. ${ }^{66}$ The courtroom negatively affects the child's recollection of the incident and studies have shown that the quality of evidence improves when given in a private room. ${ }^{67}$

In the case of $K v$ Regional Court Magistrate $N O^{68}$ Melunsky J, writing on behalf of a unanimous full bench, found that the criminal justice system is not designed adequately to meet the needs and requirements of the child witness. According to the court, in cases of sexual assault and rape, the fear of investigation and trial seriously impedes the combating of these crimes. ${ }^{69}$ The witnesses experience difficulty in comprehending the language of legal proceedings, understanding the role of the various participants and coping with the confrontation and extensive cross-examination. ${ }^{70}$ Our courts have recognized the legitimate concern on the part of most South African citizens that our criminal justice system does not give due recognition to the prominence of children's interests. ${ }^{71}$ The reality of the matter is that the innocence or guilt of the accused can be largely dependent on the competence of the role-players in the criminal justice system as well as the courtroom procedure that the child victim is subjected to.

An analysis of key legislative instruments designed to protect children in the courtroom environment, points towards a failure on the part of the legislature to give effect to children's constitutional rights that are clearly spelt out in the Constitution. ${ }^{73}$ A befitting example of a legislative provision that was designed to protect children in a courtroom environment, but does

62 Park and Renner "The Failure to Acknowledge Differences in Developmental Capabilities Leads to Unjust Outcomes for Child Witnesses in Sexual Abuse Cases" 199817 Canadian Journal of Mental Health 5 .

2008 (5) SA 578 (T).

64 S v Phaswane $S$ v Mokoena supra 232 (fn 5 above).

65 Ibid.

66 Ibid.

67 Hill and Hill "Videotaping Children's Testimony : An Empirical View" 198785 Michigan LR 809.

1996 (1) SACR 434 (E).

69 K v Regional Court Magistrate NO supra 434.

70 lbid.

71 In $S$ v Mokoena; $S$ v Phaswane supra 231 (fn 5 above), it was held that, "neither the courts nor their supporting institutions succeed in giving due recognition to the paramountcy of children's interests".

72 Conradie and Tanfa 20056 Child Abuse Research in South Africa 4; and see also s 28 of the Constitution.

$73 \mathrm{~S} 28$ emphasises the best interest of the child standard to be applied in all circumstances relating to the child. 
not achieve its desired effect is section 158 of the Criminal Procedure Act. ${ }^{74}$ The pertinent section provides for a vulnerable witness to testify by way of an electronic device such as a closed-circuit television camera.

Section 158(5) of the Act reads as follows:

"The court shall provide reasons for refusing any application by the public prosecutor for the giving of evidence by a child complainant below the age of 14 years by means of closed circuit television or similar electronic media, immediately upon refusal and such reasons shall be entered into the record of the proceedings."

The addition of section 5 of the Criminal Law (Sexual Offences and Related Matters) Amendment Act, ${ }^{75}$ which has amended section 158 of the Criminal Procedure Act, ${ }^{76}$ provides that a court must provide reasons for any refusal of an application to allow a child complainant below the age of 14 years to testify by means of electronic media or closed-circuit television. From this section, it appears that the legislature has decided to discriminate between a child complainant below the age of 14 years and those above that age. A child is a person under the age of 18 years, ${ }^{77}$ and it would be illogical for any court to distinguish between children below and above 14 years as the levels of pain, trauma and mental anguish that they experience cannot be said to vary or diminish with age. ${ }^{78}$ It is submitted that all children irrespective of their age must be given the opportunity to testify by means of electronic media or closed-circuit television. Section 158(5) of the Criminal Procedure Act, ${ }^{79}$ therefore fails to provide protection to all vulnerable minor complainants, and appears to be in direct conflict with section 28 of the Constitution. ${ }^{80}$

The principle that a trial should be held in public is entrenched in the Constitution. ${ }^{81}$ This is to ensure that the public has faith in the criminaljustice system. However, the need to protect the child witnesses from emotional and psychological harm allows the court to deviate from the aforesaid principle. Section 153 of the Criminal Procedure Act details the circumstances where a court can exclude the public from being present in open court.

The Act in the first instance deals with matters pertaining to state security and the administration of justice, ${ }^{82}$ whilst in the second instance the law

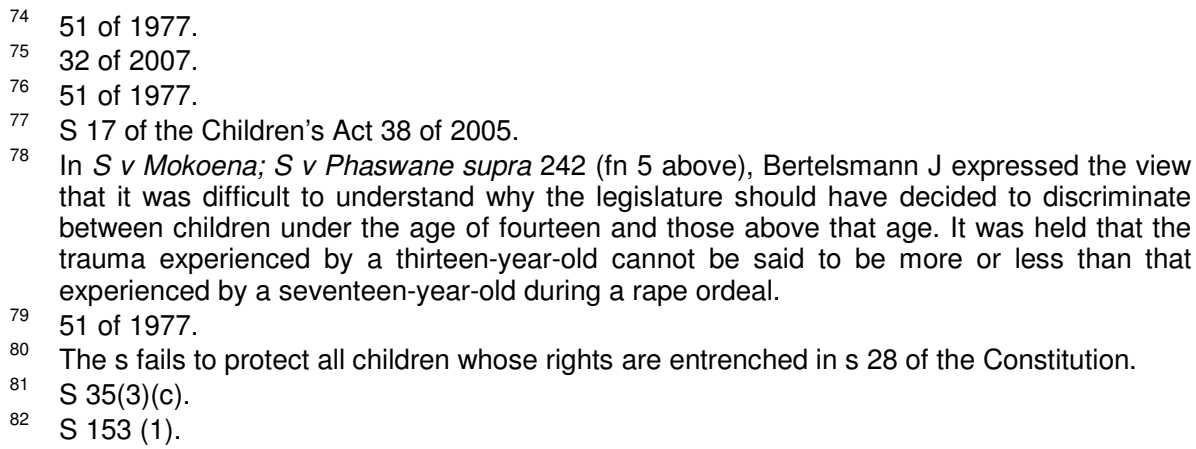

In $S$ v Mokoena; $S$ v Phaswane supra 242 (fn 5 above), Bertelsmann J expressed the view that it was difficult to understand why the legislature should have decided to discriminate between children under the age of fourteen and those above that age. It was held that the trauma experienced by a thirteen-year-old cannot be said to be more or less than that experienced by a seventeen-year-old during a rape ordeal.

7951 of 1977.

80 The $s$ fails to protect all children whose rights are entrenched in $\mathrm{s} 28$ of the Constitution.

$81 \mathrm{~S} 35(3)(\mathrm{c})$

$82 \mathrm{~S} 153(1)$. 
seeks to protect those whose lives may be exposed to possible danger if their identities are disclosed. ${ }^{83}$ Thirdly and finally, the Act confers upon the court discretion to exclude members of the public from the hearing if the minor's parent or guardian so requests, in order to protect the minor whilst also taking into account the interests of justice. ${ }^{84}$

It is our considered view that the word "may" ought not to have been used in subsection (3), as it vests the court with discretion to decide whether or not proceedings shall be in open court. This section allows the court to exclude the public in order to safeguard the interests of the child only at the request of the minor's parent or guardian. In some cases, a court might decide that that the fact that a complainant is a minor does not justify the exclusion of the public from the proceedings. ${ }^{85}$ It cannot be in the interests of justice for any court to allow the public to be present when a minor complainant testifies in court. This is a clear example of an instance where an important piece of legislation on important matters involving the vulnerable child witness appears to be in conflict with the Constitution.

The introduction of intermediaries to ease the psychological harm and trauma experienced by child witnesses in court is welcome. The use of intermediaries is specifically provided for in the Criminal Procedure Act. ${ }^{86}$

Section 170(A)(1) of the Act as amended by the Amendment Act reads as follows:

"Whenever criminal proceedings are pending before any court and it appears to such court that it would expose any witness under the biological or mental age of eighteen years to undue mental stress and suffering if he or she testifies at such proceedings, the court may, subject to subsection (4), appoint a competent person as intermediary in order to enable such witness to give his or her evidence through that intermediary."

Section $170 \mathrm{~A}(1)$ of the Act has the effect of granting a discretion to the trial court to appoint or not to appoint an intermediary when a child is called to testify in criminal proceedings. The introduction of intermediaries was brought about by legislature as an additional effort to provide protection to children who are vulnerable witnesses. Therefore, the appointment of an intermediary for child victims is a must in all criminal matters due to the mental anguish and trauma experienced by the child in a foreign environment and therefore there should be no discretion conferred to the court. ${ }^{87}$ The appointment of an intermediary would always be in the best interests of a child. The child is exposed to as much stress and mental anguish as an adult in the daunting surroundings of a courtroom. To demand that the child victim be exposed to undue stress and suffering before the

\footnotetext{
$S$ 153(2).

$\mathrm{S} 153(3)$.

In $S$ v Mokoena; $S$ v Phaswane supra 241 (fn 5 above) it was held that removing the word "may" will take away the discretion that a court has to refuse an application for proceedings not to be held in open court where the minor or the parents or guardians of such a minor bring the said application.

86 S 170A which was amended in 2001.

87 S v Mokoena; S v Phaswane supra 237 (fn 5 above).
} 
services of an intermediary may be considered is illogical. ${ }^{88}$ Section $170 \mathrm{~A}(1)$ fails to provide the necessary protection to child complainants as set out in the Constitution.

Section $170 \mathrm{~A}(7)$ of the Act gives courts a discretion to appoint or not appoint an intermediary when a child is required to testify in a criminal court.

Section $170 \mathrm{~A}(7)$ of the Act as amended by the Amendment Act reads as follows:

"The court shall provide reasons for refusing any application or request by the public prosecutor for the appointment of an intermediary in respect of child complainants below the age of 14 years, immediately upon refusal and such reasons shall be entered into the record of the proceedings.'

However, quite often intermediaries do not attend court on the trial date, resulting in lengthy postponements which are definitely not in the interests of the child. ${ }^{89}$ Some of the intermediaries that do attend have not received adequate training to assist the child through the entire court process. ${ }^{90}$ Courts also tend to underutilize intermediaries due to the belief that a child's mental anguish and stress are inevitable in sexual-offence matters and the services of intermediaries would only be required if such stress became undue. $^{91}$ We submit that the appointment of an intermediary be made mandatory in all criminal matters involving a child witness since it is difficult to think of a situation where the appointment of an intermediary would not be in the best interests of a child. Therefore, once again, key legislation that was purportedly introduced to protect the child in criminal proceedings appears to be in conflict with the Constitution.

The conviction rate in trials involving minor complainants is extremely low. One of the reasons for the low conviction rate is that children are prevented from testifying as soon as the presiding officer concludes that the child is unable to differentiate between truth and falsehood. ${ }^{92}$ Section 164(1) of the Criminal Procedure Act, which has been amended by the Criminal Law

Ibid.

89 See Waterhouse 20084 Criminal Justice Initiative Occasional Paper 14-31 on this specific issue and others such as the critical shortage of social workers and poorly trained intermediaries manning dedicated sexual-offences courts. lyer, the first author in this article, did personally experience the problem of intermediaries not attending court on the trial date at the erstwhile Legal Aid Board in Empangeni where he worked as a supervising attorney.

90 See the discussion on intermediaries in $S$ v Mokoena; $S$ v Phaswane supra 237 (fn 5 above), where the court ordered that s $170 \mathrm{~A}(1)$ of the Criminal Procedure Act be declared unconstitutional.

91 The use of the word "undue" in this context is to be found in s 170A(1) of the Criminal Procedure Act 51 of 1977. In S v Mokoena supra 599C-E (fn 63 above), Bertelsmann J questioned the constitutionality of the provision to the extent that it placed a limitation upon the best interests of the child as provided for in section 28 of the Constitution by requiring that the appointment of an intermediary for a child victim be resorted to only when it can be proved that the child would be exposed to undue stress and suffering (authors' own emphasis).

92 In $S \vee V 1998$ (2) SACR 651 (C), Rose-Innes J held that, if a child does not understand the oath and what it means to speak the truth, then the child cannot be admonished under section 164(1) and is therefore an incompetent witness whose evidence is inadmissible. 
(Sexual Offences and Related Matters) Amendment Act, does not allow a child who is unable to distinguish a truth from a lie to testify in court.

The pertinent section 164(1) of the Act reads as follows:

"Any person, who is found not to understand the nature and import of the oath or the affirmation, may be admitted to give evidence in criminal proceedings without taking the oath or making the affirmation: Provided that such person shall, in lieu of the oath or affirmation, be admonished by the presiding judge or judicial officer to speak the truth."

The proviso to section 164(1) implies that a child, who displays difficulty in differentiating between truth and falsehood, is automatically incompetent to testify in court. However, the section fails to take into account that a witness, due to her tender years may not be able to explain or detail her understanding of abstract concepts such as truth and falsehood, but that the witness may still be able to illustrate their ordeal, even if it be with the assistance of devices such as puppets and dolls. It is therefore appropriate to conclude that this section clearly conflicts with the best interests of the child standard and the Constitution.

There is no doubt that there has been an effort on the part of the legislature to introduce new legislation in order to fill the gap in the criminaljustice system but it appears that such measures have failed to have the desired effect. The criminal-justice system continues to face "critical systematic challenges" ${ }^{\prime \prime 4}$ when it comes to protecting the interests of the child victim.

\section{THE ISSUE OF LEGAL REPRESENTATION}

Despite statutory reforms having been introduced to improve the position of the child complainant in rape matters, there is still a wide gap between these legislative instruments and the reality of a criminal justice that fails to protect the interests of the child at all material times during the criminal process.

The rights that a child has in terms of the Constitution ${ }^{95}$ are supplemented by the Children's Act, ${ }^{96}$ which is expressly aimed at recognizing children's rights in practice. The issue of legal representation and lack of protection for children in a courtroom environment has given rise to the notion of a justice chasm in this area.

The Children's Act ${ }^{97}$ outlines the need to protect a child from any physical or psychological harm that may be caused by legal or administrative proceedings in relation to the child. ${ }^{98}$ The Children's Act ${ }^{99}$ also emphasizes

93 In Moekoena, the High Court raised several constitutional issues, one being the constitutionality of $s 170 \mathrm{~A}(1)$ and the other being the constitutionality of $s 170(A)(7)$ which provided for the use of intermediaries. The court held that there should be no discretion to appoint an intermediary or not - it should be mandatory in all matters involving children.

S v Mokoena; S v Phaswane supra 251 (fn 5 above).

95 Act 108 of 1996.

$96 \quad 38$ of 2005.

97 lbid.

98 See s 7(1). 
the need for children appearing before the children's court to be represented by a legal representative if it would be in the best interests of the child to have legal representation. ${ }^{100}$

The abovementioned statutes have been designed with the purpose of ensuring that proceedings are adapted to put children at ease in a courtroom environment. However, unlike in Children's Courts, the procedure in mainstream criminal courts does not contemplate special legal representation for children who are complainants in sexual matters such as rape. This leaves open the question as to whether a criminal court dealing with incidents of child rape and sexual assault affords due recognition to the paramount interests of the child when that child is deprived of legal representation in cases where it would be in the best interests of the child to have such representation.

In our view, the South African criminal justice system appears to be lagging behind other areas of law when it comes to protecting the rights of a child in a courtroom environment. A recent case that drives this point home is the matter of Legal Aid Board $v R^{101}$ In this case, Wallis AJ held that in divorce matters where parties are contesting the issue concerning care of the minor child, substantial injustice to the child would result if the child were not afforded the assistance of a legal practitioner to ensure that the voice of the child is heard. ${ }^{102}$

The Children's $\mathrm{Act}^{103}$ provides for legal representation in all matters brought before the children's court. In civil proceedings, the Constitution provides for children to be assigned a legal practitioner by the state. It is only in criminal proceedings that a child complainant is prejudiced by the lack of protection through the appointment of a legal representative in a court of law. Despite Mokoena's case's setting the tone for an overhaul of the criminal-justice system in matters involving children, the court missed an ideal opportunity to address adequately the contentious issue of providing legal representation for child complainants in criminal matters - an issue which would have gone a long way in protecting the child in a courtroom environment. Bertelsmann J, only went as far as to say, "apart from the chronic shortages that already exist in the numbers of child psychologists, correctional and probation officers as well as intermediaries, which would be exacerbated if another functionary were to be introduced in the court setting, too little evidence was placed before the court to enable it to properly define the role of such a person for the purposes of this judgment." 104

\footnotetext{
38 of 2005.

$\mathrm{S} 55$.

2009 (2) SA 262 (D).

102 See generally but on a related note Mahlobongwane "Determining the Best Interests of the Child in Custody Battles: Should a Child's Voice be considered? 201031 Obiter 232-246.

38 of 2005.

104 S v Mokoena; S v Phaswane supra par 179G.
} 
A landmark application for legal representation for minor complainants in criminal proceedings was raised in the matter of $S v$ McKenna. ${ }^{105}$

Interestingly, the application was not made by the state, but by the advocate instructed to watch over proceedings by the complainant's family. The basis for the application was to prevent an invasion of the child's constitutional rights to privacy and dignity. ${ }^{106}$ The legal representative applied for permission to be allowed to object to any improper or irrelevant questions put to the complainant by the prosecution or the defence. The court went on to dismiss the application on the basis that the regional court did not have the jurisdiction to grant the relief sought. The fact that legal representation was raised in the regional court indicates the compelling need to consider such a form of representation as a support mechanism that could effectively address the shortcomings outlined in the criminal justice system. The High Court in Mokoena did have the jurisdiction to deal with the matter, and it is disappointing that Bertelsmann $\mathrm{J}$, did not see the need to embark on such an "uncharted course".

\section{IS SEPARATE LEGAL REPRESENTATION THE ANSWER?}

It is important to consider the conceptual difficulties that one can anticipate with regard to the proposal to introduce separate legal representatives for child complainants into the South African criminal-justice system. In the past, it has been asserted that the adversarial system in South Africa cannot accommodate any form of third-party representation. ${ }^{107}$ The substantive objections to the introduction of separate legal representatives can be summarized as follows: ${ }^{108}$

- That the accused's right to a fair trial may be infringed, more so the constitutional right to challenge evidence;

- the victim is adequately protected by the presiding officer and prosecutor during the trial and the advent of an additional person into the proceedings will complicate matters and serve no purpose; and

- a separate legal representative will serve a secondary prosecutorial role and this would render their position insignificant.

The opposition to a separate legal representative often evolves around the concern that the notions of justice and equality would be disrupted as the accused would face "two prosecutors". However, few countries adopt a model where the separate legal representative serves a secondary prosecutorial role and, if the representation was limited, to filling the gaps in the criminal justice system and given the substantial safeguards available to an accused in the South African criminal justice system, it is hard to see

105 The case is unreported. The application was made in the Knysna Regional Court in October 2009.

$106 \mathrm{~S} 14$ and 10 of the Constitution of the Republic of South Africa respectively.

107 The South African Law Commission (2002) Discussion Paper 102, Project 10796.

108 Ibid. 
what prejudice may arise to an accused. ${ }^{109}$ We strongly believe that the introduction of separate legal representatives for child complainants will have the effect of improving the confidence of the victim in the criminal justice system.

For the reasons outlined in the ensuing paragraphs, a separate legal representative can be beneficial to the criminal process during the following stages:

- at the report stage;

- at the investigation stage;

- at the decision to prosecute when pre-trial support and advice is offered;

- representation during trial; and

- post-trial representation.

Studies have shown that victims who had received legal representation felt more satisfied with the trial process, including the giving of evidence and being cross-examined by the defence. ${ }^{110}$ These victims found it easier to access information when they had a lawyer and the lawyer was the main source of information. ${ }^{111}$ The presence of the legal representative will ensure that the complainant is provided with all the necessary and relevant information that is required in order to prepare for trial. The role of the victim will be clearly outlined and the complainant will be prepared emotionally to deal with the adversarial setting of a courtroom. This will ensure that more victims come forward and report their ordeals.

Some of the factors that undermine the reporting of cases include amongst others, the child feeling responsible for the abuse, sex being a taboo subject, the close relationship between the child and perpetrator, the lack of faith in the criminal justice system and family members hiding the abuse. ${ }^{112}$

Furthermore, the representative will be in a position to determine and limit the psychological harm that may be suffered by the victim during trial. ${ }^{113}$ The separate legal representative will also ensure that the victim's family is prepared for the trial process. ${ }^{114}$ During the trial, the separate legal representative would object to any hostile or improper questions put to the

109 The safeguards available to an accused include the presumption of innocence, the burden of proof on the state, the right to remain silent, the right against self-incrimination, the rule against hearsay amongst others.

110 Bacik, Maunsell, and Gogan "The Legal Process and Victims of Rape" 1998 http://www.drcc.ie/report/rapevic.pdf (accessed 2011-04-20).

111 lbid.

112 See specifically Waterhouse 2008 Open Society Foundation 4.

113 See UNODC 1 49-50.

114 UNODC 149 . The form of assistance contemplated is wide and may extend to services such as financial, legal, counselling, health, social and educational services, physical and psychological recovery services and other services necessary for child victim's reintegration. 
complainant but not necessarily involve him/herself in cross-examination. ${ }^{115}$ The separate legal representative will also ensure that the court makes use of all the necessary aids available to the victim such as closed-circuit cameras and intermediaries, amongst others. ${ }^{116}$ In our view, the separate legal representative will be there to fill the gaps in the criminal justice system, and provide support and scaffolding for the child victim to go through the trial.

\section{A CURSORY LOOK AT INTERNATIONAL TRENDS}

There is no doubt that the legislature has made an effort to introduce new laws aimed at protecting the rights and interests of the minor witness. However, whether these laws collectively safeguard the best interests of the child is yet to be determined. Our preliminary conclusion on the matter is that the laws are inadequate or ineffective in achieving the targeted goal. The new Criminal Law (Sexual Offences and Related Matters) Amendment Act ${ }^{117}$ was introduced specifically to afford complainants in sexual offences the most complete form of protection that the law can provide. ${ }^{118}$

In our view, the new Sexual Offences Act seems to overemphasize punitive measures towards sexual offenders and underestimates the protective measures towards complainants. The new Sexual Offences Act remains silent on key issues such as legal representation for victims, protection of vulnerable witnesses and the treatment of children in court. ${ }^{119}$ It is clear that the provision for legal representation in matters involving children is not determined by the best interests of the child standard but rather by the type of legal proceedings facing the child.

International jurisprudence is supportive of the need to protect the child in court, and we submit that key to achieving this is a mitigation of the adversarial nature of the trial. It is to international jurisprudence that our discussion of the inadequacy of the South African legal regime for the protection of the child witness in sexual offence matters now turns.

Germany allows for separate legal representation for complainants and the legal representative has the authority to involve himself fully in the actual trial with the main aim of protecting and guiding the complainant through the difficult process of cross-examination. ${ }^{120}$ Belgium and France allow for the complainant in rape matters to be legally represented in court and such a legal representative has the capacity to make submissions on behalf of the complainant, cross-examine witnesses, call witnesses on behalf of the

115 See UNODC 1 "Guidelines on Justice in Matters involving Child Victims and Witnesses of Crime, Chapter III, Principles, paragraph 8, and Chapter IX, The right to Effective Assistance" 49-50.

116 UNODC 1 par 2550.

11732 of 2007.

118 See preamble of the Act, 4 .

119 lyer and Ndlovu "Protecting Child Witnesses and Victims from "Undue" Stress and Suffering in Criminal Trials: S v Mokoena" 201024 Speculum Juris 137.

120 Bacik, Maunsell and Gogan 1998 http://www.drcc.ie/report/rapevic.pdf (accessed 2011-0420) 237. 
complainant and to object to questions put by the defence and prosecution that may infringe on the dignity and privacy of the complainant. ${ }^{121}$ England adopts a similar stance to South Africa on legal representation, but the English system ensures that only specialist prosecutors and presiding officers may deal with sexual offence matters. ${ }^{122}$ The specialist prosecutor interacts with the complainant as early as the report stage so as to ensure that that the bond that develops between them is a strong and healthy one. ${ }^{123}$

The United States of America has introduced victim familiarization programmes into the legal system which prepares the victim for the courtroom ordeal long in advance so as to limit the psychological and emotional trauma that may be suffered by the victim during the crossexamination process. ${ }^{124}$

Ireland has introduced legislation allowing for separate legal representation for complainants in applications where permission has been requested for evidence regarding their previous sexual history or character, to be led. ${ }^{125}$ The criminal justice system in Ireland has shown a significant shift towards a deeper understanding of the position of victims of violence. Victimization studies are carried out frequently and victim-impact reports are now part and parcel of the criminal justice procedure. ${ }^{12}$

Denmark, on the other hand, allows for legal representation for rape victims, but key to ensuring that the legal representative does not serve a second prosecutorial role, is allowing the legal representative to act only in the interests of the complainant on matters directly affecting the complainant. ${ }^{127}$ In other words, the legal representative may not crossexamine any of the witnesses, but can object to questions put to the complainant by the defence and the prosecution. The legal representative may also apply for the complainant to testify "in camera" or from the "hidden eye" of the accused.

\section{ANY LESSONS FOR SOUTH AFRICA?}

The South African Law Reform Commission initially considered introducing legal representation for rape victims in 2002, but rejected the idea on the basis that the "introduction of complainants as ancillary prosecutors" would be not be consistent with the "constitutional imperatives" of the state whose

121 Bacik, Maunsell and Gogan 1998 http://www.drcc.ie/report/rapevic.pdf (accessed 2011-0420) 210.

122 Temkin and Krahe Sexual Assault and the Justice Gap: A Question of Attitude (2008) 191

123 Ibid.

124 Bandes "Victim Standing" 1999 Utah LR 331.

125 S 34 of the Sex Offenders Act 2001.

126 O'Connell and Whelan "Crime Victimization in Ireland" 19964 Irish Criminal LJ 112.

127 Bacik, Maunsell and Gogan 1998 http://www.drcc.ie/report/rapevic.pdf (accessed 2011-0420) 198. 
interests are different to the complainant. ${ }^{128}$ The Commission focused on the German model whose inquisitorial system differs greatly from the adversarial system adopted by South Africa, and the argument raised by the Commission was that, following a model that provides for a second prosecutor, will only serve to prejudice the accused's constitutional right to a fair trial. The Commission unfortunately and in our view incorrectly viewed the legal representative for the victim as a second prosecutor.

The legal representative is never meant to be a second prosecutor but someone who is there to "fill the gaps" that exist in a criminal justice system that fails to protect the victim adequately. ${ }^{129}$ It is our considered view that a prosecutor cannot fill this perceived gap. This view is based on our understanding of the role of the prosecutor as not being limited to protecting exclusively the interests of the victim but also the public's interests. ${ }^{130}$ Therefore, the bundle of interests inevitably encompasses both the interests of the victim and the accused. Given that sexual offences are crimes against the state, prosecutors and presiding officers may feel that they have no obligation towards protecting the interests of the child victim. The secondary victimization of child complainants in the trial process will continue unless the key role-players work together to achieve one objective, that is to subject the victim to as little trauma as possible during the trial. The South African Law Commission chose to focus on the German model which differs radically from our system. ${ }^{131}$ It our considered view that the Danish model, based on a legal system with adversarial characteristics like ours, ought to have been adopted. ${ }^{132}$

As discussed earlier, the Danish model provides for a legal representative whose role and functions differ materially from the prosecutor. The United Nations has in the Universal Declaration of Human Rights proclaimed that children are entitled to special care and assistance. Section 28(2) of the Constitution, declares that: "the child's best interests are of paramount importance in every matter concerning the child". The concern raised by the Commission about the "states' constitutional" imperatives fails to realize that the protection of the child complainant should also be high on the agenda of "constitutional imperatives".

128 South African Law Reform Commission (2002) Discussion Paper 102, Project 107, Sexual Offences: Process and Procedure, SALRC http://www.doj.gov.za/salrc/dpapers.htm (accessed 2012-02-23).

129 The adversarial nature of the South African trial process was highlighted in $S$ v Manqaba (2005) 2 SACR 489 (W), where the court observed that, while it was common cause that children giving evidence in abuse cases might be traumatized by both the adversarial process and aggressive cross-examination (our emphasis), there was a number of measures available to protect the child witness while still ensuring a fair trial (at 397I-498D).

130 See Misty "Victims and the Criminal Justice System in South Africa" (1997) paper presented at the Centre for the Study of Violence and Reconciliation on 29 October 1997 6-7.

131 South African Law Reform Commission Report (fn 128 above).

132 Raitt "Independent Legal Representation for Complainers in Sexual Offence Trials" 2010 Research Report Commissioned by Rape Crisis Scotland 21-22. 


\section{CONCLUSION AND RECOMMENDATIONS}

Until the deficiencies in the criminal justice system are addressed, children will continue to be exposed to the harshness and reality of an adversarial environment which does little to protect them. Testifying in an adversarial environment is a stressful experience for the child complainant. ${ }^{133}$ The support for young child victims has a long-term effect on their recovery and their perception of the criminal justice system. ${ }^{134}$ South African courts may be hesitant to take the bold step in granting legal representation to child complainants on the basis that such an extension of the child's rights may infringe on the accused's rights to a fair trial, more so his constitutional right to challenge evidence. We believe that granting legal representation to child complainants would not in any way infringe on the accused's right to a fair trial because the accused is not being denied his right to cross-examine. In fact, very few countries adopt a second prosecutorial role, and the legal representative would in no way play such a role. The legal representative's role would be limited to exclusively protecting the interests of the complainant just as the defence attorney's role is limited to protecting the interests of the accused. This would include ensuring that the complainant is kept abreast of the investigation, the representative be present at trial and be allowed to object to any hostile questions put to the complainant and further be allowed to request that the complainant testify in camera. The representative should not be allowed to cross-examine the witnesses or focus on the merits of the matter. Surely, such a system would withstand any constitutional challenge raised by the defence. It will be recalled that there are sufficient safeguards for the accused - such as the presumption of innocence, rights to legal representation and the right not to testify or even make a statement to the police. Even if it were deemed that his right to a fair trial was being infringed on the basis that allowing representation to the child will diminish the naturalness of cross-examination, such a limitation would be reasonable and justifiable in an open and democratic society which views children as a vulnerable group that is in dire need of protection. ${ }^{135}$

South African law does provide for the use of support structures such as intermediaries and electronic devices outside the courtroom, and we see no reason why an additional support structure in the form of legal representation should not be allowed. The South African legal system, in the form of section 153 of the Criminal Procedure Act, does give the courts discretionary room to allow a support person in the form of a family member or friend to assist the child complainant during proceedings. This is an

${ }^{133}$ Muller "The Effect of the Accusatorial System on the Child Witness" 20004 Child Abuse Research in South Africa 2-9.

134 Hollely "Children in Court: The Role and Scope of the Support Person" 20023 Child Abuse Research in South Africa 14-17.

$135 \mathrm{~S} 36$ of the Constitution states that the rights in the Bill of Rights may be limited only in terms of law of general application to the extent that the limitation is reasonable and justifiable in an open and democratic society based on human dignity, equality and freedom. 
indication that our system is not rigid but flexible in the sense that third party representation can be accommodated.

There may never be a "perfect" system to deal with rape matters. However, South Africa needs to move towards a system free of prejudice and bias, a system which safeguards the interests of the child victim at all material times. Judges and prosecutors cannot fill this role. In an adversarial setting, the judge's role is that of a "neutral umpire" and any excessive intervention on the part of the judge to protect the complainant may trigger an appeal process. The prosecutor likewise is mandated to prosecute a crime against the state and bears no responsibility for protecting the rights and interests of the complainant. Legal representation for complainants in rape matters will definitely improve the level of confidence in our legal justice system, and ensure that the complainants' rights to privacy and dignity are respected at all times. This would in turn lead to a willingness on the part of rape victims to report such matters. Overall, it could go a considerable way towards alleviating the discontent of victims about the lack of support structures available to them within the criminal trial process. 